\title{
On Practice Teaching Reform of Tourism Management Major in Colleges and Universities
}

\author{
He Jianbo \\ School of Tourism \\ Jiangxi Science \& Technology Normal University \\ Nanchang, China
}

\author{
Wang Zhen \\ School of Foreign Languages \\ Jiangxi Science \& Technology Normal University \\ Nanchang, China
}

\begin{abstract}
China's tourism higher education has made great contributions to the development of China's tourism since it began in the late 1970s and has gone through a process of more than 40 years. However, there are still some problems in China's tourism higher education such as its poor practicality of courses, formalism of practical teaching, weak practical ability of professional teachers and backward facilities in practical teaching. From the perspective of practical ability training, the paper discusses the current situation where students majoring in tourism management lack of practical ability and finally puts forward corresponding countermeasures to provide some references for the development of tourism management major in colleges and universities.
\end{abstract}

Keywords-tourism management major; higher education; practice teaching; reform

\section{INTRODUCTION}

China's tourism higher education started in the late 1970s, marked by the birth of Shanghai Institute of Tourism .Undergraduate tourism education started in 1980, marked by the enrollment of the first undergraduate tourism students in Hangzhou university . In recent years, China's tourism higher education has established the rudiment of the discipline system, forming a complete education hierarchy system based on junior college and undergraduate education and including graduate education (including master's and doctor's), which fully demonstrates the development process and achievements of China's tourism higher education.

The rapid development of tourism has greatly promoted the development of tourism education and promoted the rapid expansion of China's tourism higher education. Tourism management professionals in Chinese universities have entered a new stage in terms of quantity and quality. However, with the rapid development of tourism education, many problems such as weak practical ability, weak ability to deal with unexpected problems in work and lack of innovative thinking exist in the graduates of tourism management trained by Chinese universities, among which the most prominent one is the poor practical ability of students. At the time of graduation, few college tourism management graduates enter the tourism industry, in other words, the industry entry rate is low, but at the same time the loss rate is high. This reflects that in the vigorous development of tourism higher education today, the contribution rate of tourism higher education to the tourism industry is very low, and the trained talents and the actual needs of the tourism market are seriously misplaced. Tourism management is an emerging practical and applied discipline. In combination with the market demand, higher education should lay more emphasis on cultivating practical and applied talents who understand both management and business. Therefore, it is urgent to reform the practical teaching of tourism management major.

\section{NECESSITY OF PRACTICE TEACHING REFORM OF TOURISM MANAGEMENT MAJOR IN COLLEGES AND UNIVERSITIES}

\section{A. The Needs of Tourism Management Specialty}

Tourism industry is an industry with strong practicality and operability, which requires practitioners to have strong practical ability. The characteristics of tourism industry also determine that the cultivation of tourism management professionals must have the characteristics of high applicability, so as to cultivate high-quality comprehensive applied talents that are truly suitable for the needs of the tourism market. This requires colleges and universities tourism management professional teaching needs to break the original education and teaching mode, carry out practical teaching, highlight the position of practical teaching in talent training, put practical teaching into practice.

\section{B. The Needs for Necessary Quality of Tourism Industry}

Tourism industry belongs to service industry, its practitioners must possess solid theoretical knowledge, skilled professional skills, but more important is the service consciousness and service attitude and service quality, and you have to master the ability to convert your theoretical knowledge into solving actual problem, can have a strong practical ability and the ability to find and settle problems. Tourism industry is a booming sunrise industry, tourism enterprises are of all kinds, the quality of tourist consumers and actual demand is extremely different. This means that tourism industry practitioners need to have a strong psychological adaptability and ability to withstand pressure. It is because many tourism management graduates do not know the art of hospitality, do not have strong practical ability and problem solving ability, but just complain about the difficulty of work, unreasonable consumers, poor quality. To solve

Sponsored by: "On Stereoscopic Practice Teaching System in Tourism Management Major in Colleges and Universities Based On Collaborative Innovation" (Teaching Reform Research Projects of Institutions of Higher Learning in Jiangxi Province, No. JXJG-15-10-19). 
these problems, it is necessary to carry out practical teaching. Only in this way can students have the necessary service consciousness and professional quality of tourism industry. Therefore, in order to solve the above problems and cultivate professionals competent for tourism management with market competitiveness, it is necessary to strengthen practical teaching and deepen practical teaching reform.

\section{Common Needs of Talents and Enterprises}

Along with the further development of China's economy and culture, tourism consumers' requirements for service quality tend to be more standardized and strict, but a lot of university tourism management graduates into tourism industry, to be going to work because of the lack of their own professional skills and practical ability, couldn't immediately be competent, work under heavy pressure and required to pass through six months or more for quite some time to adapt and to slowly grope. Therefore, on the one hand, there is a shortage of talents in tourism enterprises; on the other hand, quite a number of students majoring in tourism management who are good at academic performance but unable to complete their work independently have difficulties in employment and turn to other industries. In order to solve the above problems of tourism enterprises and talents, it is necessary to deepen the reform of practical teaching and highlight the links of practical teaching.

\section{PROBLEMS EXISTING IN PRACTICE TEACHING OF TOURISM MANAGEMENT COURSES}

\section{A. The Unsatisfactory Practicality of Tourism Management Courses}

At present, the major arrangements and courses of tourism management in colleges and universities mainly focus on theory and have poor practicality. It is mainly reflected in the following points:

\section{1) Too Many Theoretical Class Hours and Less Practice}

\section{Class Hours}

According to the course setting of tourism management major in colleges and universities in China, there are more class hours in theoretical courses such as introduction to tourism and tourism aesthetics, and less class hours in practical courses such as simulation and explanation.

\section{2) Adopt Outdated Tourism Practice Teaching Method}

The important characteristic of practice teaching is to pay attention to the cultivation of students' practical ability, which must give students the opportunity to practice. However, at present, tourism education in colleges and universities in China still follows the teaching mode of ordinary majors, pays attention to the teaching of systematic theoretical knowledge, and fails to carry out necessary practical teaching in accordance with the educational rules of tourism majors. As a result, it is difficult to cultivate tourism management talents with strong practical ability.

\section{3) Unscientific Teaching Content Setting}

Although tourism management major also pays attention to practice to some extent, the main practice teaching is limited to simple indoor practice operation, which fails to fundamentally develop students' practical ability, resulting in no qualitative improvement of students' practical ability. Some colleges and universities even cancel the link of practical teaching, making tourism management higher education lack of its own vigor and characteristics.

\section{B. Practice Teaching is a Kind of Formality}

Throughout the development of tourism higher education, for a long time, colleges and universities have not thoroughly analyzed the necessity of carrying out practical teaching in China , and have a serious lack of understanding of the status of practical teaching in tourism higher education. As a result, for a long time, the proportion of practical teaching curriculum and classes arrangement in tourism higher education is still very low. Under the influence of traditional education and teaching theories, practical teaching has not been carried out in tourism higher education. The tourism management major in Chinese colleges and universities still has many problems, such as unreasonable curriculum setting, lack of practical teaching facilities and equipment, backward practical teaching methods, still in the stage of going through the formalities, and lack of assessment system of practical teaching.

Although tourism higher education has made staged progress, the discipline construction of tourism management is still in the process of exploration and improvement. The practical teaching links affect the subject construction to some extent. Due to the lack of necessary facilities and equipment for practical teaching, backward teaching methods and so on, it is difficult to carry out practical teaching substantially, and the effect of practical teaching is even more difficult to achieve breakthrough progress.

\section{The Practice Teaching Ability of Teachers is Weak}

The construction of teaching staff plays a very important role in the cultivation of tourism talents in colleges and universities. The quality of teachers determines the quality of graduates cultivated by colleges and universities to some extent. Tourism management education in colleges and universities in China started in the late 1970s. As a new discipline, tourism management is not as perfect as other disciplines in discipline construction. At the same time, there are few teachers who are truly double-qualified. Most of the teachers of tourism management major in China are from history, geography, literature and other majors, and most of them are "halfway professionals". Therefore, they lack a systematic grasp of the discipline of tourism management and have insufficient cognition of practical teaching.

Tourism management teachers have different degrees of problems in the implementation of practical teaching and teaching evaluation. For example, teachers do not have practical experience in the tourism industry, do not know how to carry out practical teaching, or are not willing to spend time on the design of practical teaching plan, which ultimately leads to the monotonous and obsolete form of practical 
teaching method. In order to complete the teaching task, students will be arranged to practice or be on probation, and students will obviously lack of clear goals and systematic guidance in the practice process, so the result of practical teaching can be imagined. Backward part of the teachers' practice teaching method, there is not enough thinking space for the students, so the enthusiasm of students in practice and the ability of independent thinking can't receive adequate training, only teachers in the process of practical teaching, single-handedly students blindly imitate, which is inevitable to cultivate new talents with strong practical and innovative ability who can meet the needs of current tourism development

\section{The Construction of Practice Teaching Facilities and Bases is relatively backward}

Part of tourism management of higher education in our country lags behind practice base construction, and have not established stable practice bases for the student to carry on the practice teaching, leading to the teacher in class exercise singly in the classroom, even only through the video and photos to show students operation steps and methods. Students accept "spoon-feeding" education passively, cannot really carry on hands-on practice or effectively exercise their practice ability. In addition, although tourism management majors in some universities in China have established relevant training bases on campus, they do not play the role of training bases but put them on the shelf. Tourism management is a major with strong practice and application. Nowadays, traditional classroom teaching cannot meet the needs of professional teaching.

Furthermore, The construction of practice base is relatively backward. Colleges and universities have not established longterm stable internship bases, and some colleges and universities even only rely on individual contaction of teachers, lacking relative long-term, stability and control. Most of the specific conditions of the tourism enterprises vary greatly, resulting in the overall effect of students' internship differences. At the same time, the tourism industry belongs to the tertiary industry, and some tourism enterprises pay more attention to their height, appearance, language and other abilities in the selection of employees. Therefore, some students with poor ability cannot go to those units and enterprises that can train employees' comprehensive ability. There is another very serious problem in the internship of tourism management major in colleges and universities, that is, the internship time is relatively short. According to relevant data, the internship time of tourism management major in colleges and universities is usually between 3 months and 6 months, and some universities even arrange the internship time within 3 months. Such a short internship time is difficult for students to get real training in tourism enterprises.

\section{MEASURES TO PROMOTE PRACTICE TEACHING REFORM OF TOURISM MANAGEMENT MAJOR IN COLLEGES AND UNIVERSITIES}

\section{A. Improve Teaching Plan, Define Teaching Objectives and Optimize Course Design}

In order to train the comprehensive applied talents who are suitable for the demand of tourism market, it is necessary to highlight the position and the role of practical teaching in tourism higher education.

Firstly, teaching plan. Teaching plan is the overall plan of curriculum setting. The teaching plan of tourism management major should highlight the characteristics of the major and the position and role of practical teaching in talent training. The arrangement of practical teaching should reject the low-level formalized practical practice.

Secondly, teaching objectives. Teaching objective is the direction and expected result of the implementation of teaching activities and the starting point and final destination of all teaching activities. Tourism management major is a highly applicable major, and the setting of teaching objectives should also highlight the characteristics of the major. One of the main goals of practical teaching is to cultivate and improve the practical skills of students majoring in tourism management. The direction of carrying out teaching activities should emphasize the practical link.

Finally, curriculum design. The direction of the course design should define the characteristics of the major clearly, design the public basic courses, professional basic courses and professional compulsory courses reasonably, offer relevant professional elective courses, public elective courses and other complete course design systems actively .

\section{B. Establish and Improve Practice Evaluation and Assessment System.}

The efficient development of practical teaching not only requires practitioners to have the correct concept of practical teaching and grasp the correct methods of practical teaching, but also requires practitioners to carry out practical teaching effectively in the daily teaching process, without formalism and going through the formalities. Colleges and universities have to definite the requirements of practical teaching, establish and improve the evaluation and assessment system. In order to improve the status of tourism management professional teachers and students can realize the function of practical teaching in tourism higher education deeply by adopting many kinds of assessment methods, such as school evaluation, department evaluation, teacher evaluation, student evaluation and so on, which will enhance the consciousness and enthusiasm of teachers and students. 


\section{Take Practical Ability as Leading Factor and Build UpDouble-quality Teaching Staff.}

Teachers are the main body of knowledge dissemination. Strengthening practical teaching requires practitioners not only to have extensive and profound professional theoretical knowledge, but also to have considerable practical ability. In the reform of practical teaching system, tourism management majors in colleges and universities in China should strive to build a "double-qualified" teaching staff and strive to raise the practical level of teachers who major in tourism management specialty. Through "send out, bring in", strengthen the cultivation of teachers' practical ability."Send out", that is, making plans to send teachers to major tourism enterprises to study. To learn the advanced management experience and practical operation which helps teachers to improve the ability of practicing and update the content of teachers' practical teaching in school to meet the needs of the constantly developing and changing tourism industry, which makes teachers truly to be new double-qualified era teachers who integrate teaching and practicing. "Bring in" means recruiting teachers who have practical experience and recruiting full-time teachers with both academic and practical experience, which has provided tourism management new practical vitality. For example, the teachers who have been engaged in high-star hotel first-line management work or have rich travel agency management and tour guide experience. The combination of these experiences and teaching can liven up classroom atmosphere and make the experimental teaching rich and colorful. On the basis of it, integrating the experience of other backbone teachers in scientific research, planning, design and so on fully improves the level of practical teaching as a whole.

\section{Construct In-school Training Bases and Expand Off- campus Practice Bases.}

The training base is the important guarantee of carrying out training and experimental teaching. However, according to present situation, the construction of training base of tourism management specialty in colleges and universities of our country is still not perfect, and school training is the basis of practical teaching and the premise of carrying out the later practice. Colleges and universities should make great efforts to foster the practical ability of students based on actual demand of tourism market and the advanced level of social development. The training bases in the school are supposed to be built with high-standard and in accordance with the management and service of the actual work as possible, including tour guide training room, hotel room training room, bar training room and so on.

The in-school training is the basis of building up the student's practical ability, and the off-campus practice is the sublimation of students' practical ability training. Colleges and universities with tourism management major in our country should depend on major hotels, tourism hotels, tourism cooperatives and other tourism enterprises and institutions to negotiate and cooperate on the construction of training bases, cooperative schools and other issues, try their best to reach a substantial operation agreement, and establish a long-term and effective cooperation mechanism. Through this horizontal connection, we can closely contact the major tourism enterprises and construct high-quality practice base, which makes open interactive teaching and practical teaching a reality and combines production and learning.

\section{CONCLUSION}

As a sunrise industry in the 21 st century, tourism is developing vigorously. Colleges and universities should be market-oriented as the important bases of personnel training. As a consequence, tourism higher education is supposed to deepen the reform of practical teaching, carry out practical teaching effectively and try hard to cultivate practical and applied talents who adapt to the market demand of today's tourism industry. Based on the analysis of the problems exiting in practical teaching in colleges and universities and the necessity of practical teaching, this article puts forward that it's necessary to cultivate all kinds of professionals at all levels of tourism industry with strong comprehensive ability and not only carry out the education of theoretical knowledge, but also pay attention to the cultivation of practical ability.During the process of cultivating talents, tourism management majors in colleges and universities ought to perfect teaching plans, clarify teaching objectives, optimize curriculum design, establish and perfect practical teaching assessment and evaluation system, build up double-quality teaching staff, taking practical ability as the leading role and construct in-school training bases actively and expand offcampus practice bases at the same time. Only by doing well in all of these fields can the practical teaching of tourism management specialty in colleges and universities be a reality, and then a large of practical and applied talents with high literacy can be trained for tourism industry. In this case, the future of tourism industry will be more brilliant and glorious.

\section{REFERENCES}

[1] Xu Anfeng. Han Zhongchun. Exploration on Practice Teaching Reform of Tourism Management Specialty in Colleges and Universities[J], Educational Research and Experiment, 2009(S2):85-87.

[2] Zhou Songxiu, Wang Peng. Research on Teaching Reform of the Practice of Tourism Management in Colleges and Universities[J]. Journal of Hengyang Normal University, 2007(03):180-182.

[3] Guo Liyu, Yang Shangying. Du Zhongchao. On Teaching Reform of Tourism Management for Training of Innovative Tourism Talents[J]. Journal of Xianyang Normal University, 2009(04):86-89.

[4] Wang Jian. On Teaching Reform of Professional Practice of Tourism Management[J]. Education Teaching Forum, 2013(36):24-25.

[5] Zhang Yugai, Lan Guiqiu. On Teaching Reform of Professional Practice of Tourism Management in Colleges and Universities[J]. Journal of Heilongjiang Vocational Institute of Ecological Engineering, 2009(01):125-126.

[6] Zhong Haofan, Lv Huaxian. On Practice Teaching of Tourism Management Major of Province-owned Local Colleges[J]. Journal of Guangxi Open University, 2019(04):49-51.

[7] Liu Jing. On Construction of "1+3+6" Practice Teaching Mode in Tourism Management Major of Application-oriented Universities[J]. Journal of Sichuan Tourism University, 2019(04)1-4.

[8] Li maolin. On Training of Practical Abilities of Undergraduates Majored in Tourism management[J]. Journal of Jiamusi Vocational Institute, 2017(11):251+253. 